Prepared for the U.S. Department of Energy

under Contract DE-AC05-76RL01830

\title{
Improvement of capabilities of the Distributed Electrochemistry Modeling Tool for investigating SOFC long term performance
}

RG Galdamez

KP Recknagle

April 2011

Pacific Northwest

NATIONAL LABORATORY

Proudly Operated by Battelle Since 1965 


\title{
DISCLAIMER
}

This report was prepared as an account of work sponsored by an agency of the United States Government. Neither the United States Government nor any agency thereof, nor Battelle Memorial Institute, nor any of their employees, makes any warranty, express or implied, or assumes any legal liability or responsibility for the accuracy, completeness, or usefulness of any information, apparatus, product, or process disclosed, or represents that its use would not infringe privately owned rights. Reference herein to any specific commercial product, process, or service by trade name, trademark, manufacturer, or otherwise does not necessarily constitute or imply its endorsement, recommendation, or favoring by the United States Government or any agency thereof, or Battelle Memorial Institute. The views and opinions of authors expressed herein do not necessarily state or reflect those of the United States Government or any agency thereof.

\author{
PACIFIC NORTHWEST NATIONAL LABORATORY \\ operated by \\ BATTELLE \\ for the \\ UNITED STATES DEPARTMENT OF ENERGY \\ under Contract DE-AC05-76RL01830
}

Printed in the United States of America
Available to DOE and DOE contractors from the Office of Scientific and Technical Information,
P.O. Box 62, Oak Ridge, TN 37831-0062;
ph: (865) 576-8401
fax: $(865)$ 576-5728
email: reports@adonis.osti.gov

\begin{abstract}
Available to the public from the National Technical Information Service, U.S. Department of Commerce, 5285 Port Royal Rd., Springfield, VA 22161 ph: (800) 553-6847 fax: $(703) 605-6900$ email: orders@ntis.fedworld.gov online ordering: http://www.ntis.gov/ordering.htm
\end{abstract}

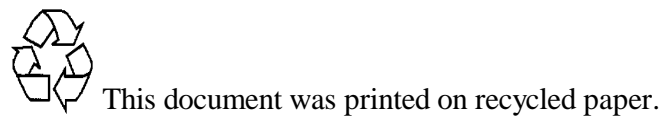




\section{Improvement of capabilities of the Distributed Electrochemistry Modeling Tool for investigating SOFC long term performance}

RG Galdamez

KP Recknagle

April 2011

Prepared for the U.S. Department of Energy under Contract DE-AC05-76RL01830

Pacific Northwest National Laboratory

Richland, Washington 99352 
Improvement of capabilities of the Distributed Electrochemistry Modeling Tool for investigating SOFC long term performance

\author{
RG Galdamez ${ }^{1}$, KP Recknagle ${ }^{2}$ \\ ${ }^{1}$ Florida International University, ${ }^{2}$ Pacific Northwest National Laboratory
}

This report provides an overview of the work performed for Solid Oxide Fuel Cell (SOFC) modeling during the 2012 Winter/Spring Science Undergraduate Laboratory Internship at Pacific Northwest National Laboratory (PNNL). A brief introduction on the concept, operation basics and applications of fuel cells is given for the general audience. Further details are given regarding the modifications and improvements of the Distributed Electrochemistry (DEC) Modeling tool developed by PNNL engineers to model SOFC long term performance. Within this analysis, a literature review on anode degradation mechanisms is explained and future plans of implementing these into the DEC modeling tool are also proposed.

\title{
1. Introduction
}

Fuel cells offer a clean, viable alternative to generate electricity at high efficiencies. Similar to a battery, a fuel cell converts chemical energy to electrical and thermal energy by a direct and continuous conversion process of supplied fuel and oxidant. Compared to conventional electrical energy production systems, fuel cells offer several advantages including high efficiency, reliability, fuel adaptability and low levels of pollution.

A fuel cell is composed of 3 layers: an anode which is porous and allows fuel flow to the electrolyte. It also serves as a catalyst for the oxidation of fuel. The electrolyte, which could be aqueous or solid depending on the type of fuel cell, is a layer with high ionic conductivity that permits hydrogen ions or oxygen ions to travel from the cathode to the anode where the chemical reactions will take place. Finally, the cathode is a thin porous layer where oxygen reduction takes place. Figure 1 shows the different elements that compose a fuel cell.

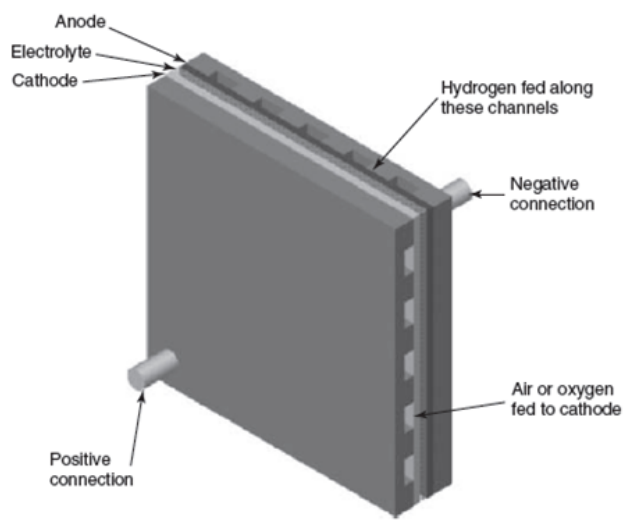

Figure 1: Elements of a fuel cell [1] 
There are many different types of fuel cell technologies, depending on the types of fuel used, materials and electrochemical reactions that take place through the electrodes. One of the most noticeable differences is also the operating temperature. Polymer Electrolyte Membrane (PEMFC), Alkaline (AFC) and Phosphoric Acid (PAFC) typically operate at a temperature range of $100^{\circ} \mathrm{C}-400^{\circ} \mathrm{C}$. This type of fuel cell is typically used as backup and auxiliary power generation units, transportation as well as military or even aerospace applications as can be seen in Table 1.

Table 1: Comparison of fuel cell technologies [2]

\begin{tabular}{|c|c|c|c|c|c|c|c|}
\hline $\begin{array}{l}\text { Fuel Cell } \\
\text { Type }\end{array}$ & $\begin{array}{l}\text { Common } \\
\text { Electrolyte }\end{array}$ & $\begin{array}{c}\text { Operating } \\
\text { Temperature }\end{array}$ & $\begin{array}{c}\text { Typical Stack } \\
\text { Size }\end{array}$ & Efficiency & Applications & Advantages & Disadvantages \\
\hline $\begin{array}{l}\text { Polymer } \\
\text { Electrolyte } \\
\text { Membrane } \\
\text { (PEM) }\end{array}$ & $\begin{array}{l}\text { Perfluoro } \\
\text { sulfonic acid }\end{array}$ & $\begin{array}{l}50-100^{\circ} \mathrm{C} \\
122-212^{\circ} \\
\text { typically } \\
80^{\circ} \mathrm{C}\end{array}$ & $<1 \mathrm{~kW}-100 \mathrm{~kW}$ & $\begin{array}{c}60 \% \\
\text { transpor- } \\
\text { tation } \\
35 \% \\
\text { stationary }\end{array}$ & $\begin{array}{l}\text { - Backup power } \\
\text { - Portable power } \\
\text { - Distributed generation } \\
\text { - Transporation } \\
\text { - Specialty vehicles }\end{array}$ & $\begin{array}{l}\text { - Solid electrolyte re- } \\
\text { duces corrosion \& electrolyte } \\
\text { management problems } \\
\text { - Low temperature } \\
\text { - Quick start-up }\end{array}$ & $\begin{array}{l}\text { - Expensive catalysts } \\
\text { - Sensitive to fuel impurities } \\
\text { - Low temperature waste } \\
\text { heat }\end{array}$ \\
\hline $\begin{array}{l}\text { Alkaline } \\
\text { (AFC) }\end{array}$ & $\begin{array}{l}\text { Aqueous } \\
\text { solution of } \\
\text { potassium } \\
\text { hydroxide } \\
\text { soaked in a } \\
\text { matrix } \\
\end{array}$ & $\begin{array}{l}90-100^{\circ} \mathrm{C} \\
194-212^{\circ} \mathrm{F}\end{array}$ & $10-100 \mathrm{~kW}$ & $60 \%$ & $\begin{array}{l}\text { - Military } \\
\text { - Space }\end{array}$ & $\begin{array}{l}\text { - Cathode reaction faster } \\
\text { in alkaline electrolyte, } \\
\text { leads to high performance } \\
\text { - Low cost components }\end{array}$ & $\begin{array}{l}\text { - Sensitive to } \mathrm{CO}_{2} \\
\text { in fuel and air } \\
\text { - Electrolyte management }\end{array}$ \\
\hline $\begin{array}{l}\text { Phosphoric } \\
\text { Acid } \\
\text { (PAFC) }\end{array}$ & $\begin{array}{l}\text { Phosphoric } \\
\text { acid soaked } \\
\text { in a matrix }\end{array}$ & $\begin{array}{l}150-200^{\circ} \mathrm{C} \\
302-392^{\circ} \mathrm{F}\end{array}$ & $\begin{array}{l}400 \mathrm{~kW} \\
100 \mathrm{~kW} \\
\text { module }\end{array}$ & $40 \%$ & - Distributed generation & $\begin{array}{l}\text { - Higher temperature enables CHP } \\
\text { - Increased tolerance to fuel } \\
\text { impurities }\end{array}$ & $\begin{array}{l}\text { - Pt catalyst } \\
\text { - Long start up time } \\
\text { - Low current and power }\end{array}$ \\
\hline $\begin{array}{c}\text { Molten } \\
\text { Carbonate } \\
\text { (MCFC) }\end{array}$ & $\begin{array}{l}\text { Solution } \\
\text { of lithium, } \\
\text { sodium, and/ } \\
\text { or potassium } \\
\text { carbonates, } \\
\text { soaked in a } \\
\text { matrix } \\
\end{array}$ & $\begin{array}{l}600-700^{\circ} \mathrm{C} \\
1112-1292^{\circ} \mathrm{F}\end{array}$ & $\begin{array}{c}300 \\
k W-3 \mathrm{MW} \\
300 \mathrm{~kW} \\
\text { module }\end{array}$ & $45-50 \%$ & $\begin{array}{l}\text { - Electric utility } \\
\text { - Distributed generation }\end{array}$ & $\begin{array}{l}\text { - High efficiency } \\
\text { - Fuel flexibility } \\
\text { - Can use a variety of catalysts } \\
\text { - Suitable for CHP }\end{array}$ & $\begin{array}{l}\text { - High temperature cor- } \\
\text { rosion and breakdown } \\
\text { of cell components } \\
\text { - Long start up time } \\
\text { - Low power density }\end{array}$ \\
\hline $\begin{array}{l}\text { Solid Oxide } \\
\text { (SOFC) }\end{array}$ & $\begin{array}{l}\text { Yttria stabi- } \\
\text { lized zirconia }\end{array}$ & $\begin{array}{l}700-1000^{\circ} \mathrm{C} \\
1202-1832^{\circ} \mathrm{F}\end{array}$ & $1 \mathrm{~kW}-2 \mathrm{MW}$ & $60 \%$ & $\begin{array}{l}\text { - Auxiliary power } \\
\text { - Electric utility } \\
\text { - Distributed generation }\end{array}$ & $\begin{array}{l}\text { - High efficiency } \\
\text { - Fuel flexibility } \\
\text { - Can use a variety of catalysts } \\
\text { - Solid electrolyte } \\
\text { - Suitable for CHP \& CHHP } \\
\text { - Hybrid/GT cycle }\end{array}$ & $\begin{array}{l}\text { - High temperature cor- } \\
\text { rosion and breakdown } \\
\text { of cell components } \\
\text { - High temperature opera- } \\
\text { tion requires long start up } \\
\text { time and limits }\end{array}$ \\
\hline
\end{tabular}

Solid Oxide Fuel Cells (SOFC) are high-temperature fuel cells, operating at temperatures between $700^{\circ} \mathrm{C}$ and $1000^{\circ} \mathrm{C}$. It is not necessary to use expensive catalysts since the rate of electrochemical reactions increases with temperature. Also, they provide fuel flexibility, there is no need to use purified fuel and any impurities in the fuel (such as carbon monoxide) would not affect its operation. Given its high operating temperature, SOFCs have internal reforming capability. As it can be observed in Table 1, SOFCs have relatively low manufacturing cost, are highly efficient, and their efficiency can increase if used in a combined heat and power (CHP) system. A CHP system recovers the excess heat output by the fuel cell and provides hot water to a building by means of a heat exchanger. Therefore an SOFC can be both an electrical and thermal source of energy. Other uses also include military applications, electric utility power source, and auxiliary power for transportation [2]. Figures 2 and 3 show images of a CHP and auxiliary power unit used in transportation. 


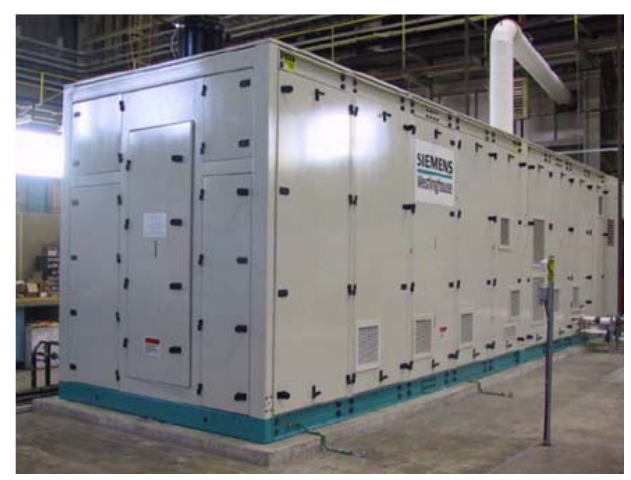

Figure 2: Siemens-Westinghouse SOFC combined heat and power system [3]

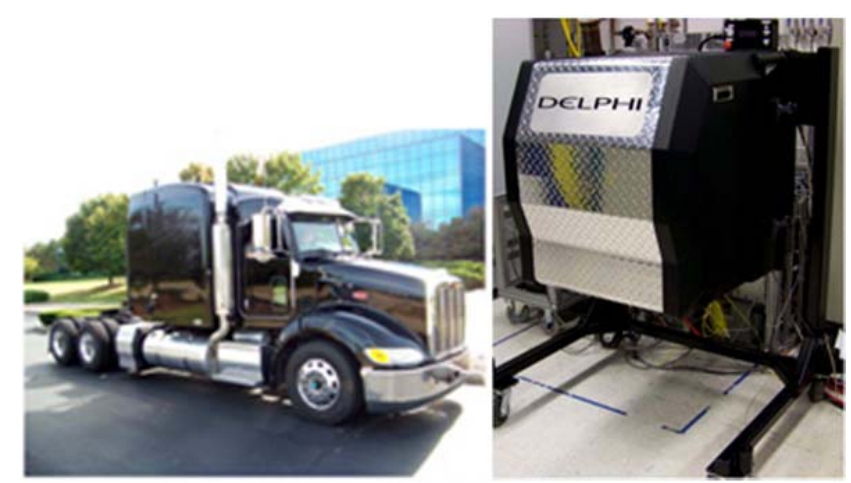

Figure 3: Delphi SOFC auxiliary power unit [3]

\section{Project Description}

This research project is part of the Department of Energy's (DOE) National Energy Technology Laboratory (NETL) Solid-State Energy Conversion Alliance (SECA) Core Technology Program.

PNNL involvement is to provide expertise and analysis in the numerical modeling of the multiphysics involved in SOFC performance analysis.

SECA's goal is to advance SOFC technology through government-industry partnerships. Collaboration is promoted between Core Technology research and development teams and industry that develop these proprietary technologies. Given its internal reforming capabilities, SOFCs are especially attractive for SECA since the ultimate goal is to develop a low cost, high performance and robust fuel cell technology that can be integrated for large coal-fueled central generation systems. This is in alignment with the Clean Coal Power Initiative (CCPI) Program from DOE [4].

\section{Modeling methods and results}

SOFCs are modeled at an operating temperature of $800^{\circ} \mathrm{C}$, with a tri-layer composed of a non-porous ceramic electrolyte made of Yttrium-doped zirconium oxide (YSZ), an anode made 
of Ni/YSZ cermet composite and a cathode manufactured of Lanthanum Strontium Manganite (LSM) [5].

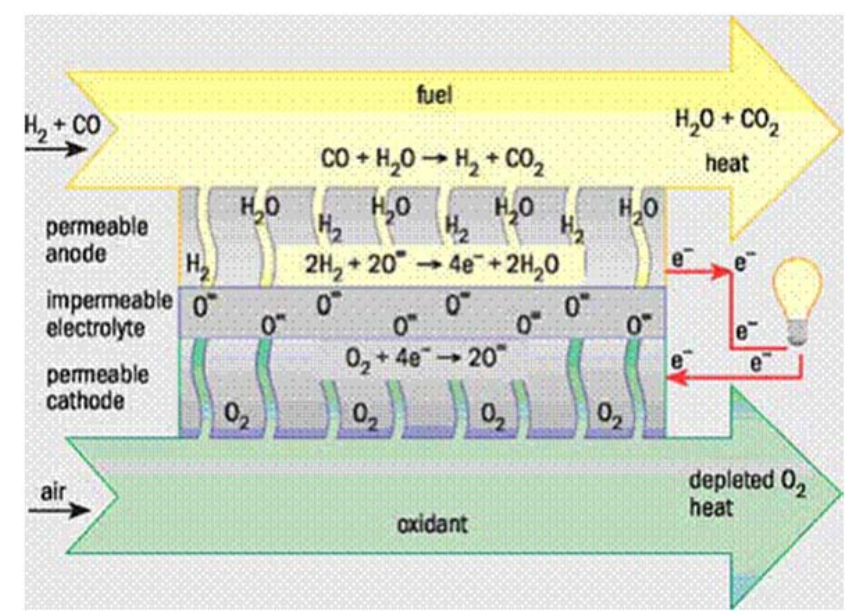

Figure 4: Working chemistry principles of an SOFC [6]

There can be a wide variety of species considered in the fuel stream: $\mathrm{H}_{2}, \mathrm{H}_{2} \mathrm{O}, \mathrm{CO}, \mathrm{N}_{2}, \mathrm{Ar}$, $\mathrm{CO}_{2}, \mathrm{CH}_{4}, \mathrm{O}_{2}$, He. There have been numerous simulation efforts at PNNL focusing on modeling capabilities and numerical analysis of the performance of SOFCs.

PNNL has developed a Distributed Electrochemistry (DEC) Modeling Tool in order to further the development of computer models to predict SOFC performance and degradation. The commercial computational fluid dynamics (CFD) code STAR-CD is used to solve for fluid, reactive species and electric field calculations. A continuum scale effective properties approach is used for the calculation of particle size, pore size, porosity, tortuosity, volume fractions of $\mathrm{Ni}$ and YSZ as well as the conductivities of the materials in the tri-layer [7]. Recent electrochemistry models are used to resolve the charge transfer, electric potential, and species through the electrodes [8-10]. Surface chemistry reactions are also taken into account and calculated using CHEMKIN.

Given that the expect lifetime of an SOFC is 40,000 hours; there is an increasing interest in developing models to analyze the long term performance of SOFC.

The main challenge in modeling and analyzing the long term performance of the SOFC is to account for all the mechanisms involved in the anode degradation process. Several modifications and improvements were made to the DEC modeling tool in order to integrate such processes. The CHEMKIN routines were activated and its output to STAR-CD was debugged. New gas species present at the anode were added, in order to consider a wide range of fuel gas mixtures. There are two important components that are of interest $\mathrm{Ni}(\mathrm{OH})_{2(\mathrm{~g})}$ and $\mathrm{Ni}(\mathrm{O})_{(\mathrm{s})}$. The STAR-CD model setup is shown in Figure 5. 


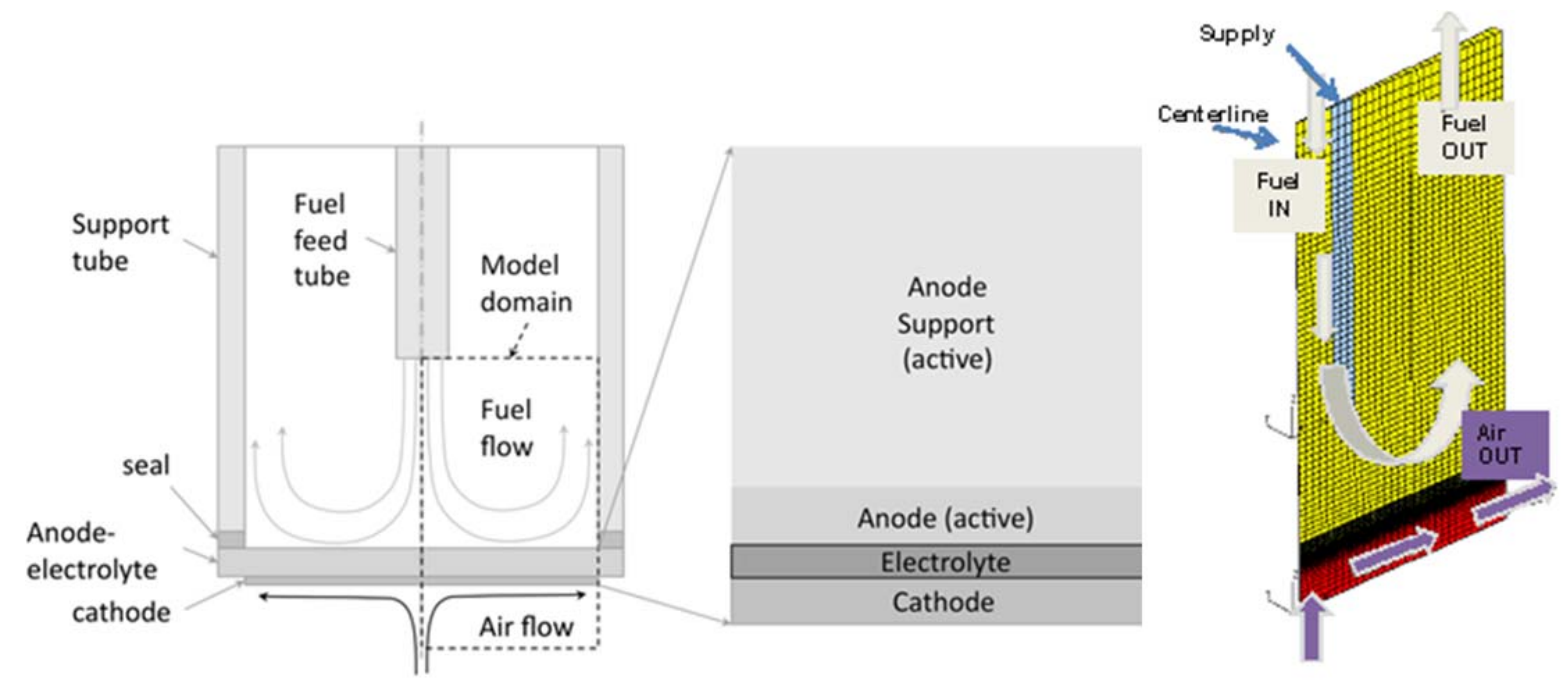

Figure 5: Schematic of the simulation domain (shown within the dashed lines) [7]

Table 2: Structural parameters for simulation $[7,11]$

\begin{tabular}{|c|c|c|c|c|c|c|c|}
\hline & \multicolumn{3}{|c|}{ Volume Fraction } & \multicolumn{2}{|c|}{$\begin{array}{c}\text { Particle Radius, } \\
\text { um }\end{array}$} & \multirow{2}{*}{$\begin{array}{c}\text { Pore } \\
\text { radius, } \\
\mu \mathrm{m}\end{array}$} & \multirow{2}{*}{$\begin{array}{l}\text { Tortuosity } \\
\text { factor }\end{array}$} \\
\hline & YSZ & Pores & $\mathrm{Ni} / \mathrm{LSM}$ & YSZ & $\mathrm{Ni} / \mathrm{LSM}$ & & \\
\hline Anode & 0.274 & 0.35 & 0.376 & 0.5 & 0.5 & $0.5 / 0.8$ & 2.5 \\
\hline Electrolyte & 1.0 & 0.0 & 0.0 & - & - & - & - \\
\hline Cathode & 0.315 & 0.35 & 0.335 & 0.5 & 0.5 & 0.5 & 2.5 \\
\hline
\end{tabular}

Table 3: Fuel composition

\begin{tabular}{cc}
\hline Specie & $\begin{array}{c}\text { Mass } \\
\text { fraction }\end{array}$ \\
\hline $\mathrm{H} 2$ & $9 \%$ \\
$\mathrm{O} 2$ & $0 \%$ \\
$\mathrm{H} 2 \mathrm{O}$ & $69 \%$ \\
$\mathrm{CO}$ & $1 \%$ \\
$\mathrm{CO} 2$ & $2 \%$ \\
$\mathrm{~N} 2$ & $1 \%$ \\
$\mathrm{CH} 4$ & $19 \%$ \\
\hline
\end{tabular}



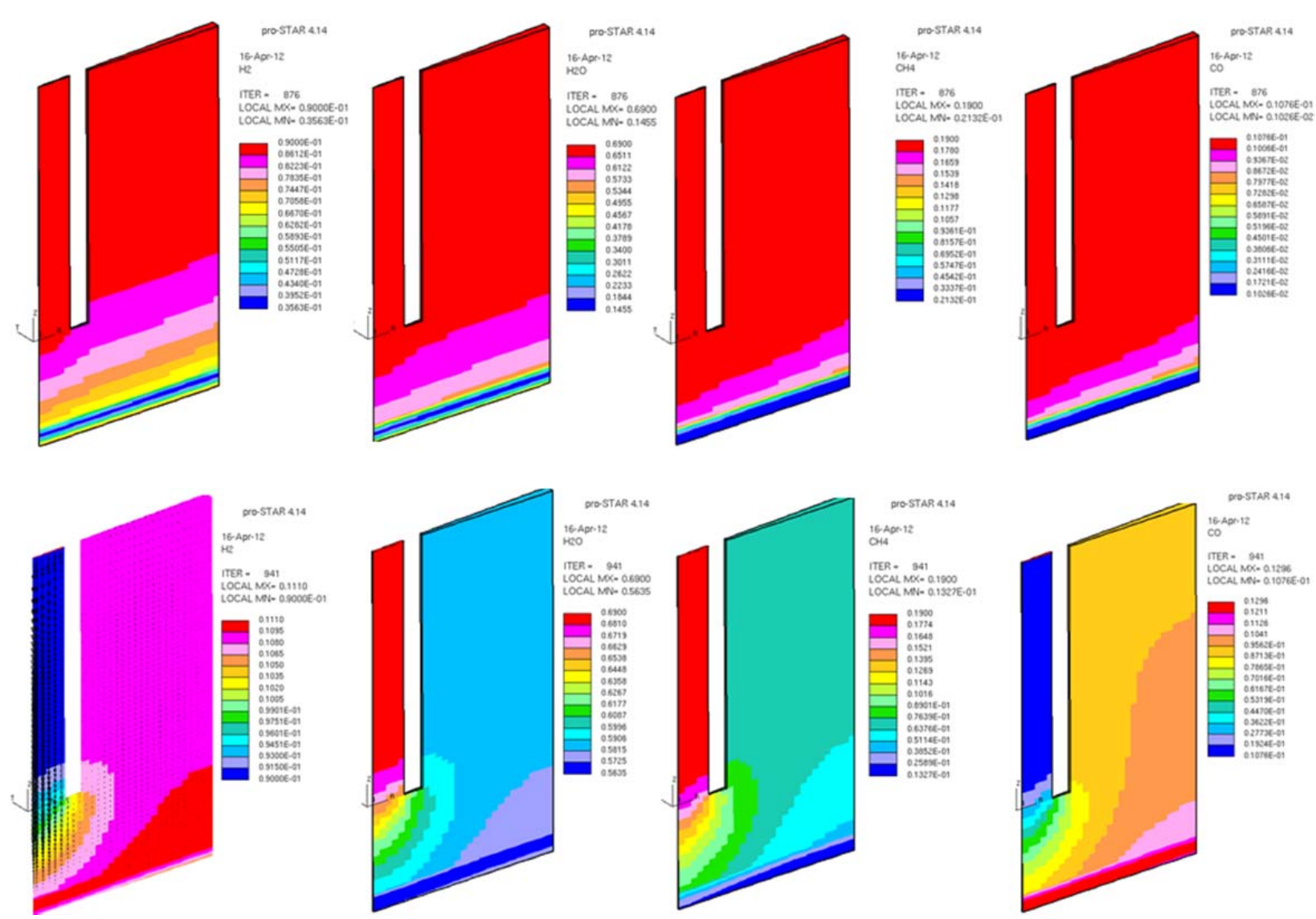

Figure 6: Simulation results. Top: without CHEMKIN surface chemistry. Bottom: with CHEMKIN

Figure 6 shows the simulation results with and without the CHEMKIN surface kinetics routine activated. A clear difference can be observed between the two sets of results. Given the fuel composition in Table 3, this is a methane reforming simulation. It is expected that with CHEMKIN active in the calculations, $\mathrm{CH}_{4}$ would reform; $\mathrm{CO}$ would be produced as well as water as byproducts of the reforming reaction. In both cases, $\mathrm{H}_{2}$ is consumed as part of the regular oxidation of the fuel. There is clearly a higher production of $\mathrm{H}_{2} \mathrm{O}$ and $\mathrm{CO}$ and higher consumption of $\mathrm{CH}_{4}$ with CHEMKIN active; therefore the reactions occurring at the surface of the triple phase boundary (TPB) of the Ni, YSZ and fuel are being accounted for in the numerical calculations.

\section{Long term degradation}

The long term performance of an SOFC is directly correlated to the long term degradation of the Ni/YSZ anode. This degradation is thought to be due to several mechanisms such as the local degradation of the triple-phase boundary where the reactions need to take place between the $\mathrm{Ni}$, YSZ and the fuel phases. There is a Ni volatilization phenomena that appears to happen an is currently being investigated by several researchers. This vaporization-deposition seems to be 
driven by a humidity gradient through the anode [12]. Moreover, this influence of fuel humidity and also cell voltage in the degradation rates has been analyzed $[13,14]$ and it is believed to play a role in Ni volatilization. There has been evidence of some interstitial hydroxyls on the surface of YSZ at the electrolyte which may have an influence on the TPB and therefore on the overall degradation of the anode [15].

Unfortunately the vast majority of these degradation studies are done on a short term basis; there are few publications available with results of 10,000 hours or more of testing $[16,17]$. Thyden performed an extended study of SOFC degradation with more than 17,000 hours of continuous operation. A linear cell voltage drop was observed after 8000 hours of operation and by the end of the experiment more than $50 \%$ of the YSZ contact points were lost or weakened. The TPB was also degraded and its length decreased by around the same percentage [17]. Therefore, the performance of the cell decreases given that reactions at the TPB can no longer take place. It was also inferred that the deposition of $\mathrm{Ni}$ on YSZ could be influenced by the humidity gradient present at the anode. This confirms that the volatilization of $\mathrm{Ni}$ into $\mathrm{Ni}(\mathrm{OH})_{2}$ as stated previously, is also a mechanism involved in the long term degradation process of the anode.

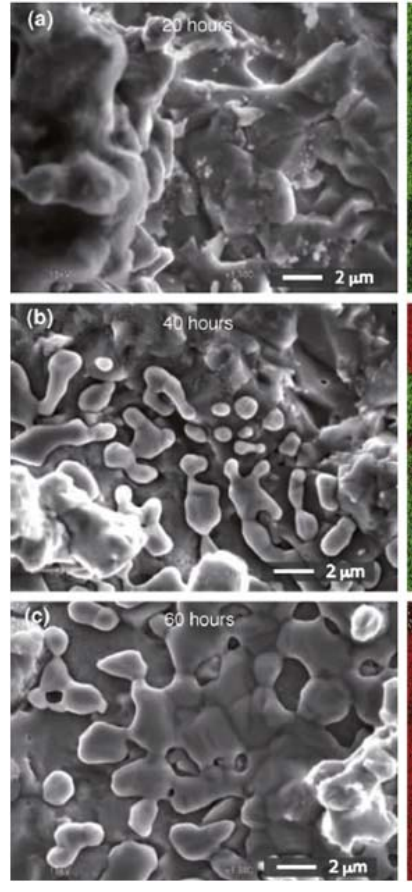

(a)

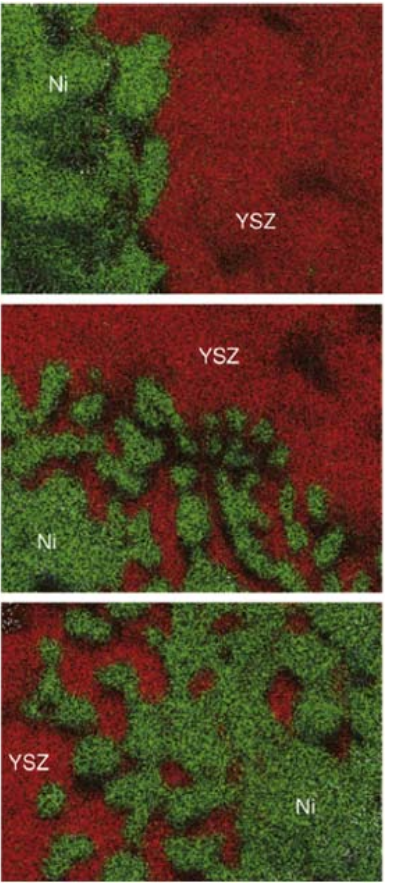

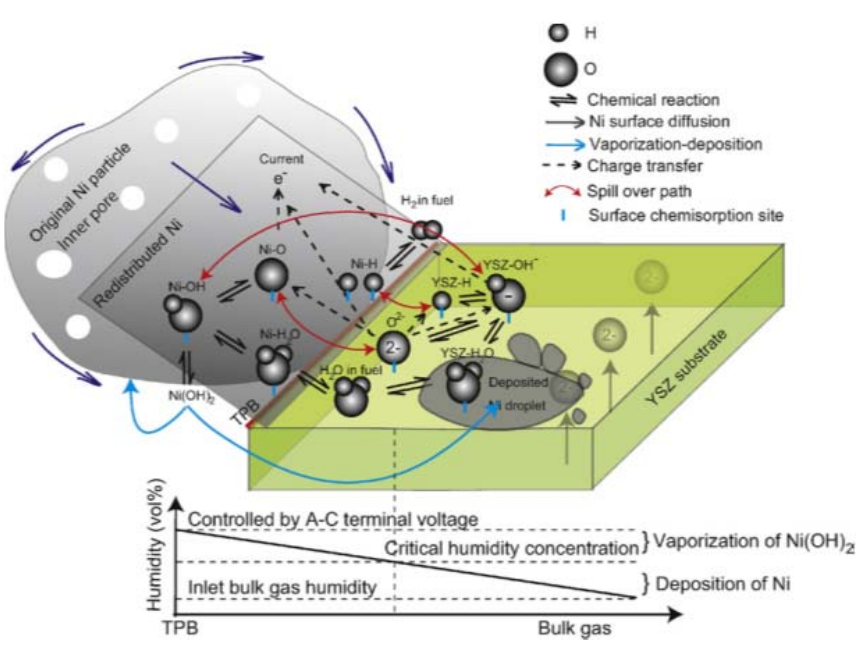

(b)

Figure 7: (a) Ni morphology after testing, (b) Ni vaporization-deposition process [12]

Figure 7 shows images of the Ni morphology after 20, 50 and 60 hours of testing. It can be seen how Ni droplets are formed after 40 hours and these later deposit and interlock at the opposite side on the surface of the YSZ. This is evidence of the Ni volatilization mechanism 
discussed previously. Figure 7(b) provides a schematic description of this vaporizationdeposition process. At the surface reactions, $\mathrm{Ni}$ volatilizes in the form of $\mathrm{Ni}(\mathrm{OH})_{2(\mathrm{~g})}$ which travels by humidity gradient to the electrolyte $\mathrm{YSZ}$, deposits as $\mathrm{Ni}(\mathrm{O})_{(\mathrm{s})}$ then gets reduces to $\mathrm{Ni}_{(\mathrm{s})}$ on the YSZ.

\section{Conclusions and future work}

The DEC modeling tool is an important resource to understand and predict long term SOFC performance and degradation. This tool can be used both by research and industry teams to further develop SOFCs into a robust and highly dependable technology to provide clean electricity in coal-fueled generation systems. Among other technological and research challenges, anode degradation is a very complex problem, yet to be completely understood. Known issues such as $\mathrm{Ni}$ volatilization can be implemented in the DEC model in order to simulate SOFC conditions on a long term basis. As part of the future work to be done in this project, further literature and results need to be found on these degradation mechanisms in order to validate the numerical model. The Ni volatilization, $\mathrm{NiO} / \mathrm{Ni}$ deposition and presence of $\mathrm{OH}$ can be accounted for in the STAR-CD routines and will be properly integrated into the existing calculations.

\section{Acknowledgments}

This research internship was sponsored by the DOE Office of Science, Science Undergraduate Laboratory Internship Program at PNNL. This project is part of the Solid-State Energy Conversion Alliance Core Technology Program by DOE's National Energy Technology Laboratory. Special thanks to Karen Wieda for her continuous support and encouragement.

\section{References}

[1] J. Larminie and A. Dicks, "Fuel Cell Systems Explained (2nd Edition)," ed: John Wiley \& Sons.

[2] "Fuel Cell Technologies Program," ed: U.S. Deparment of Energy, Office of Energy Efficiency and Renewable Energy, 2011.

[3] Fuel Cell Handbook, 7 ed. Morgantown, WV: National Energy Technology Laboratory, 2004.

[4] (April 16). Solid State Energy Conversion Alliance (SECA). Available: http://www.netl.doe.gov/technologies/coalpower/fuelcells/seca/

[5] K. P. Recknagle, E. M. Ryan, B. J. Koeppel, L. A. Mahoney, and M. A. Khaleel, "Modeling of electrochemistry and steam-methane reforming performance for simulating pressurized solid oxide fuel cell stacks," Journal of Power Sources, vol. 195, pp. 6637-6644, 2010.

[6] S. C. Singhal. (2008, April 16). Solid Oxide Fuel Cells. Available: http://electrochem.cwru.edu/encycl/art-f02-sofc.htm 
[7] K. P. Recknagle and E. M. Ryan, "Numerical Modeling of the distributed electrochemistry and performance of solid oxide fuel cells," in ASME 2011 International Mechanical Engineering Congress \& Exhibition, Denver, CO, 2011.

[8] W. G. Bessler, S. Gewies, and M. Vogler, "A new framework for physically based modeling of solid oxide fuel cells," Electrochimica Acta, vol. 53, pp. 1782-1800, 2007.

[9] H. Zhu and R. J. Kee, "Modeling Distributed Charge-Transfer Processes in SOFC Membrane Electrode Assemblies," Journal of The Electrochemical Society, vol. 155, pp. B715-B729, 2008.

[10] H. Zhu, R. J. Kee, V. M. Janardhanan, O. Deutschmann, and D. G. Goodwin, "Modeling Elementary Heterogeneous Chemistry and Electrochemistry in Solid-Oxide Fuel Cells," Journal of The Electrochemical Society, vol. 152, pp. A2427-A2440, 2005.

[11] Y. Jiang and A. V. Virkar, "Fuel Composition and Diluent Effect on Gas Transport and Performance of Anode-Supported SOFCs," Journal of The Electrochemical Society, vol. 150, pp. A942-A951, 2003.

[12] Z. Jiao, N. Takagi, N. Shikazono, and N. Kasagi, "Study on local morphological changes of nickel in solid oxide fuel cell anode using porous Ni pellet electrode," Journal of Power Sources, vol. 196, pp. 1019-1029, 2011.

[13] S. Koch, P. V. Hendriksen, M. Mogensen, Y. L. Liu, N. Dekker, B. Rietveld, B. de Haart, and F. Tietz, "Solid Oxide Fuel Cell Performance under Severe Operating Conditions," Fuel Cells, vol. 6, pp. 130-136, 2006.

[14] T. Matsui, R. Kishida, J.-Y. Kim, H. Muroyama, and K. Eguchi, "Performance Deterioration of Ni--YSZ Anode Induced by Electrochemically Generated Steam in Solid Oxide Fuel Cells," Journal of The Electrochemical Society, vol. 157, pp. B776-B781, 2010.

[15] A. Gorski, V. Yurkiv, D. Starukhin, and H.-R. Volpp, "H2O chemisorption and H2 oxidation on yttria-stabilized zirconia: Density functional theory and temperature-programmed desorption studies," Journal of Power Sources, vol. 196, pp. 7188-7194, 2011.

[16] C. Comminges, Q. X. Fu, M. Zahid, N. Y. Steiner, and O. Bucheli, "Monitoring the degradation of a solid oxide fuel cell stack during 10,000 h via electrochemical impedance spectroscopy," Electrochimica Acta, vol. 59, pp. 367-375, 2012.

[17] K. Thyden, "Microstructural Degradation of Ni-YSZ Anodes for Solid Oxide Fuel Cells," PhD, Fuel Cells and Solid State Chemistry Department, University of Copenhaguen, Roskilde, Denmark, 2008. 